\title{
A motivációk és az életstílus hatása a sportfogyasztás területeire
}

\author{
Csóka László \\ Pécsi Tudományegyetem
}

\begin{abstract}
A TANULMÁNY CÉLJA
A tanulmány célja a sportfogyasztás szakirodalma alapján lehatárolni olyan területeket, ahol a szakirodalom tovább gazdagítható, kijelölve ezzel lehetséges jövőbeli kutatási irányokat. A sportmarketinges szakemberek a sportfogyasztást klasszikusan három kategóriára, a sportolásban való aktív részvételre, az események élményként történő fogyasztására és a sporttermékek vásárlására osztják, amely kategóriák esetén a vizsgálatokat egymástól külön választva végzik. Az egyes kategóriák dimenziójában elkülönítetten végzett vizsgálatok miatt értékes információk maradhatnak rejtve a kutatók és ezáltal a gyakorlati szakemberek elől. A tanulmány további célja ráirányítani a figyelmet az átfogó érvényú jelenségekre, amivel a sportfogyasztási kérdéseket a kategóriák teljes keresztmetszetében is megvizsgálva lehetővé válna a folyamatok jobb megértése.
\end{abstract}

\section{ALKALMAZOTT MÓDSZERTAN}

Megállapításainkhoz a szakirodalom széles körét felhasználva szakirodalmi áttekintés típusú tanulmányt készítettünk.

\section{LEGFONTOSABB EREDMÉNYEK}

A fogyasztás szempontjából célszerủ lenne a sportfogyasztás klasszikus felosztását kiterjeszteni és azt további két kategóriával bővíteni. Igaz ez a sportfogyasztási motivációk kutatása esetén is, mivel elszigetelt vizsgálatból sok van, átfogó szemléletüből ezzel szemben kevés. Fontos lenne vizsgálni a sport iránti alapvető érdeklődés (motiváció) hatásait a sportfogyasztási kategóriákra, ami újdonságot jelentene a jelenleg népszerủ kategória-specifikus kutatásokhoz képest. Új kutatási irányt jelent az életstílus hatásának vizsgálata is a sportfogyasztásra és a sportfogyasztási motivációkra. Az életstílus szerepét számos kutató elismeri a sportfogyasztásban, a szakirodalom mégis szegényesnek tekinthető az ilyen típusú kutatások terén.

\section{GYAKORLATI JAVASLATOK}

A tanulmányban meghatározott kutatási irányok alapján a feltárható ismeretek birtokában a sporthoz kapcsolódó vállalatok pontosabban tudnának szegmentálni, célcsoportokat meghatározni, ami megteremtené a jobb pozícionálás lehetőségét is. Napjaink sportgazdaságában a számos szereplő és az éles verseny miatt ez kulcskérdést jelenthet adott sportvállalat sikerességének szempontjából.

Kulcsszavak: sportfogyasztás, fogyasztói magatartás, életstílus csoportok, sportmarketing

Köszönetnyilvánittás: A kutatás azEmberi Erőforrás Fejlesztési Operatív Program, EFOP-3.6.2-16-2017-003: „Sport- Rekreációs- és Egészséggazdasági Kooperációs Kutatóhálózat létrehozása” címủ projektjének támogatásával készült.

DOI: 10.15170/MM.2020.54.KSZ.III.01 


\section{A SPORTFOGYASZTÁS ÉRTEL- MEZÉSE \\ INTERPRETATION OF SPORT CONSUMPTION}

Gazdasági szempontból napjainkban a sport szerepe megkérdőjelezhetetlen. Olyan jövedelmezö piacgazdasági szegmenssé vált, amely a szórakoztató és a szolgáltató ipar szerves részét képezi (Szabó 2015). Az országok lakosai szabadidejük jelentős részét töltik olyan típusú szolgáltatások fogyasztásával, amik a sporthoz köthetők, így a sport különböző ágaiban jelentős beruházásokat eszközölnek a vállalatok (Salgado-Barandela $e t$ al. 2017, Szakály - Fehér 2015).

A sport gazdasági hozzájárulásának mértékét bizonyítja a sport iparágának a GDP-hez való hozzájárulása. A szük értelemben vett Vilniusi definíció szerint 2012-ben az Európai Unió GDP-jének 1,13\%-ához (112,18 milliárd $€$ ) járult hozzá a sport. Ez az érték a tágabb értelemben vett definíció szerint viszont eléri a $1,76 \%$-ot $(173,86$ milliárd $€)$ is. Ha figyelembe vesszük az indirekt hatásokat a GDP esetében, akkor a multiplikátor hatásnak köszönhetően a sport az Európai Unió GDP-jének 1,88\%-ához (186,2 milliárd €) járul hozzá a szük értelmezés, míg 2,98\%-ához (294,35 milliárd $€$ ) a tág értelmezés szerint (SpEA 2012).

Ahhoz, hogy a sport ilyen mértékben hozzájáruljon a gazdasághoz, alapvetően a sport üzletté válása szükséges. Ez akkor következik be, ha a sporttevékenységek végzéséhez vagy annak nézőként történő figyelemmel kíséréséhez a szükségletek fogyasztói igényként jelentkeznek, amit a sportra szakosodott profitorientált vállalatok elégítenek ki (András - Máté 2016). Ennek kiindulópontja egy adott sportág népszerüsége, ami a nézőszámon keresztül mérhető. A nézőszám növekedése egy bizonyos szint után kiváltja a média érdeklődését, ami magával hozza a marketingcéllal közeledő vállalatok figyelmét is. Ennek hatására adott sport piacán megjelennek a profitorientált szereplők, mint például a sportügynökségek, ligák, hivatásos esemény-szervezők, amik az adott sport kapcsán termékeket és szolgáltatásokat alakítanak ki (Walker \& Enz 2006, Hargitai 2013). Az ilyen sport termékek és szolgáltatások lehetőséget biztosítanak az emberek számára a sport tulajdonképpeni fogyasztására, amely sportfogyasztás bevételt generál a fentiekben jelzett profitorientált szereplők számára, és ezáltal hozzájárul a gazdaság egészéhez. A sportfogyasztás emiatt a sport gazdasági jelentőségének értelmezésében alapvető (Ács és tsai 2018).
A sportfogyasztás vizsgálata szokásos szemléletben három nagy elemből tevődik össze, amelyek a sportolásban történő (profi vagy amatőr) aktív részvétel, a sporttermékek és szolgáltatások fogyasztása, illetve a sportesemények nézőként történő (online vagy offline) fogyasztása személyesen vagy a médián keresztül (Stewart et al. 2003). A sportolásban való aktív részvétel során a sportfogyasztás akkor realizálódik, amikor az egyén saját maga vesz részt valamilyen aktív sporttevékenységben, idejét, energiáját és pénzét áldozva erre. A szakirodalom ezt a típusú fogyasztást a legtöbbször aktiv sportfogyasztásnak nevezi (Neulinger 2007). Belátható, hogy az egyén saját maga is közvetlenül kiveszi a részét a folyamatból, ami alapvető különbséget jelent a sportfogyasztás második eleméhez képest, amikor nézőként vesz részt a sportolásban. Ez passzív sportfogyasztásnak tekinthető (Neulinger 2007), mivel közvetett részvételről beszélhetünk, amely során a sportterméket mások hozzák létre, így az egyén csak passzív élvezője a folyamatnak, vagyis a sport által nyújtott élményt fogyasztja. A sportélmény fogyasztása szintén időt, energiát és pénzt igénylő tevékenység, legyen szó annak akár online, akár offline változatáról. Az offline sportélmény fogyasztáshoz sorolható a sporteseményeken való részvételen túl a jegyvásárlás, az odajutás, a helyben fogyasztott ételek-italok köre, és az ajándéktárgyak helyben történő vásárlása is. Az online sportélmény fogyasztás esetében az események közvetítésen vagy felvételeken történő megtekintésén túl jelentheti a sporthírek, az egyes sportolók életének, sportágak történéseivel foglalkozó közlemények figyelemmel követését is, de a saját sporttevékenység eredményének online regisztrálását és megosztását is a különböző digitális platformokon. A sportfogyasztás harmadik elemét a sporttermékek és szolgáltatások fogyasztása jelenti, amelyhez a különféle sporteszközök, azok használatával és müködtetésével kapcsolatos szolgáltatások, a sportoláshoz kapcsolódó, azt segítő szolgáltatások tartoznak (Csóka - Törőcsik 2018).

A szakirodalmakat áttekintve érdekes jellemző, hogy a sportfogyasztói magatartással foglalkozó szakirodalom az egyes kategóriák között aszimmetrikus, a kutatások nagy része a sporttevékenységekben történő aktív részvétel, illetve a sporteseményeken való személyes részvétel sajátosságaival foglalkozik. A sporttermékek fogyasztásának, illetve a médián keresztüli sportesemények jellemzőinek vizsgálata kevésbé fajsúlyos, az előző két kategóriánál jóval szerényebb szakirodalmi forrás található a sportfogyasztás ezen kategóriáinak sajátosságairól (Csóka 2019, Fernandes et al. 2013). 
Ez következhet abból, hogy a sportfogyasztás egyes kategóriái közül a sporttermékek és szolgáltatások fogyasztása hasonlít leginkább a marketing klasszikus szakirodalmában leírtakhoz, így a gyakorlati marketingmunkában kevésbé igényel egyedi megközelítést. Ehhez képest a sportolásban való aktív és nézői részvétel a marketing klasszikus szakirodalmában foglaltakhoz képest már jóval speciálisabb esetnek tekinthető. Speciális abból a szempontból, hogy esetükben a fogyasztás többségében nem a funkcionális, hanem inkább emocionális, és a fogyasztók érintettsége is jelentősen magasabb. További különbséget jelent, hogy ezen kategóriák fogyasztói magatartásának megértésében a demográfiai jellemzők a teljes kép csak egy szeletét jelentik (Mullin et al. 2014).

A sporteseményekhez kapcsolódó nézői részvétel és az egyes sportágakban való aktív jelenlét elemzése is igen érdekes, hiszen a fogyasztók sokszor generációtól, nemtől vagy jövedelmi helyzettől függetlenül kerülnek ki. A magyar sportcsapatoknak és az egyéni sportolóknak szurkolók demográfiai összetételét vizsgálva teljesen egyértelmü, hogy a szurkolók arányát tekintve nem feltétlenül vannak nemek közötti különbségek (bár ez erősen sportágfüggő), sőt generációs és jövedelmi különbségek is csak minimális mértékben. A sportolásban való aktív részvétel esetén a demográfia már vegyesebb képet mutat. Egyes sportágak végzése fizikailag megterhelőbb, míg mások kevésbé, aminek köszönhetően a megterhelőbb sportágakban föként a fiatalabb generációk és nagyobb arányban a férfiak vesznek részt. Az ilyen típusú sportágak aktív fogyasztásában a demográfia egyértelmú befolyásoló hatással bír, míg a fizikailag kevésbé megterhelö sportágakban más tényezők nagyobb hatást gyakorolnak (Törőcsik - Csóka 2018).

Összességében a demográfiai jellemzők helyett a sportolásban való aktív és a nézői részvétel esetén a környezeti hatások és az egyén pszichográfiai jellemzői azok, amik erőteljes hatást gyakorolnak a fogyasztásra. Az ilyen típusú sportfogyasztást föként a sportág, a sportcsapat vagy a sportoló személyének szeretete határozza meg, amit leginkább a kulturális normák, a referencia és aspirációs csoportok, az érzések, az érzékelése, a motivációk, az attitüd, az életstílus, az életíven elfoglalt hely és egyéb személyes jellemzők befolyásolnak (Mullin et al. 2014).

\section{A SPORTFOGYASZTÁS MÖGÖTT HÚZÓDÓ MOTIVÁ- CIÓK ÉS AZOK VIZSGÁLATA THE MOTIVATIONS OF SPORT CONSUMPTION AND THEIR INVESTIGATION}

A sportiparban tevékenykedő vállalatok számára a fentiekben bemutatott sajátos tulajdonságok miatt felértékelödik a fogyasztók pszichográfiai jellemzőinek megismerése a piaci stratégiájuk kialakításában és a célszegmenseik kiválasztásában. Az ilyen típusú vizsgálatok között népszerủ a sportfogyasztók motivációjának feltárása és megismerése. Számos kutatás született a sportolásban történö közvetlen, illetve a sportesemények nézöként történő fogyasztás motivációinak feltárására különböző skála kutatásokkal. Ezek célja többségében az, hogy olyan skálákat hozzanak létre, amelyek alkalmasak a sportfogyasztási motivációk mérésére, és ezáltal a sportfogyasztói magatartás egy területének feltérképezésére (Paic és tsai 2018, Kajos és tsai 2017).

A sportolás motivációit mérő skálák közül a legjelentősebb a Pelletier és társai (1995) által megalkotott 7 faktorból és 28 itemböl álló SMS (Sports Motivation Scale) skála, amelynek eredeti verzióját elöször francia, majd angol nyelven validáltak tudományosan megalapozott empirikus módszerrel (Pelletier et al. 1995). A skála sikerességét bizonyítja, hogy számos idézés köthető a skála eredeti publikációjához (Web of Science é.n.), valamint az, hogy megalkotása után több nyelvre lefordították, illetve több országban validálták (Paic és tsai 2018). Az eredeti skálát több kritika is érte, így ezen kritikák alapján többen próbálták az eredeti frissített verzióját elkészíteni, aminek eredményeképpen létrejött az SMS-6, illetve a BRSQ skála, amelyek ugyanazt a keretrendszert alkalmazzák, mint az SMS skála (Lonsdale et al. 2014). Az SMS skála megalkotói, reagálva a kritikai észrevételekre, illetve az új módosított skálák létrejöttére, megalkották az SMS skála továbbfejlesztett változatát az SMS2-t (Pelletier et al. 2013). Ezt a skálát az SMS skálához hasonlóan számos nyelvre lefordították, illetve validálták több országban, köztük Magyarországon is, ami kiemelkedő jelentőségü kutatásunk szempontjából (Paic és tsai 2018). Szakirodalmi kutatásunk alapján megállapítható, hogy az SMS2 skála nevezhető a sportolásban való aktív részvétel motivációinak mérésére alkalmas skálák közül a legszélesebb körben alkalmazottnak. 
A sportfogyasztás másik kategóriájának, a sporteseményeken nézőként történő részvétel, esetében a szurkolói motivációt mérő skálák találhatók. Ezek közül egyike az elsőknek a Wann (1995) által készített SFMS skála (Sport Fan Motivation Scale), amely 8 faktor és 23 item alapján méri a szurkolói motivációt. Az SFMS skála létrejötte után több skála is született a témakörben, mint pl. a Milne és McDonald (1999) által készített MSC (Motivations of the Sport Consumer), a Trail és James (2001) által létrehozott MSSC (Motivation Scale for Sport Consumption), illetve a Funk és munkatársai (2001) által létrehozott SII (Sport Interest Inventory). Ezen skálák mindegyikét tudományosan megalapozott módszerrel empirikusan validálták, azonban a felhasználhatóságuk szük körre érvényes, mivel specifikusan egyes sportágak, főként amerikai csapatsportok vizsgálatára fejlesztették ki öket. Ebböl következően nem használhatók átfogóan, minden egyes sportág esetében a szurkolók motivációinak mérésére, ezekhez általában a módosításuk szükséges. Ezt a problémát részben áthidalandó készítették el Funk és társai (2009) a SPEED skálát, amivel egy általános skála létrehozása volt a céljuk. Ezen skála segítségével a csapatsportok szurkolóinak motivációi sportágtól függetlenül mérhetők. A SPEED skála kiemelkedik a többi szurkolói motivációt mérő skála közül azért is, mert az általános használhatóságán túl kevésbé komplex, mint a korábbi skálák, így a tudományos célok mellett a gyakorlatban is jól alkalmazható, a szakemberek által akár a csapatok mérkőzései során is lekérdezhető (Kajos és tsai 2017).

A motivációs skálakutatások esetén érdekes, hogy a médián keresztüli nézői sportfogyasztás és a sporttermékek és szolgáltatások fogyasztásának motivációit mérő skálák szakirodalma igencsak szegényes. Nagyságrendileg kevesebb kutatás foglalkozik az ezen kategóriák esetén tapasztalható fogyasztás motivációival, így a szakirodalom ezen a téren is aszimmetrikusnak tekinthető (Csóka 2019), ráadásul átfogó keretrendszert sem sikerült azonosítani, ami a sportfogyasztási kategóriákon átívelve a sport iránti alapvető motivációt mérné.

\section{ÉLETSTLUS-KUTATÁSOK ÉS ÉLETSTÍLUSCSOPORTOK LIFESTYLE RESEARCH AND LIFESTYLE GROUPS}

A sportfogyasztás sajátosságainak értelmezése során számos szerző említi a pszichográfiai jellemzők közül a motivációk mellett az életstílus kiemelkedő szerepét is. A vonatkozó szakirodalmi kutatás során mégis az volt a tapasztalat, hogy külön a sportfogyasztást középpontba helyező életstílus-kutatás nem született. Ha áttekintjük az életstílus-kutatások jellemzőit akkor ez a helyzet még nagyobb ür észlelését jelenti, hiszen az életstílus egyértelmüen jelentős hatást gyakorolhat a sportfogyasztásra (Mullin et al. 2014). Ezzel mégsem foglalkozott kimondottan a sportra fókuszálva még egyetlen kutató sem.

Az életstílus-kutatások a szociológiában már az 1960-as években elkezdődtek Alfred Adler kutatásaival. Adler ugyan az emberek egyediségét vallotta, de kutatásaiban kimutatta, hogy az emberek az életstílusukban hasonlíthatnak egymásra, így csoportokba rendezhetők (Matzler et al. 2004). Nem sokkal később 1964-ben Lazer bevezette az életstílus kérdéskörét a marketing világába fogyasztói kutatásokon keresztül. A marketingben a téma egyre népszerübbé vált, és a kutatók számos eszközt fejlesztettek, amik alkalmasak a fogyasztók életstílus-csoportok alapján történő szegmentálására. Kiderült, hogy az életstílusnak jelentős hatása van a mindennapi fogyasztói magatartásra, az életstílus alapjaiban befolyásolja a fogyasztói döntéseket (Füller \& Matzler 2008). Ennek köszönhetően a marketingben az életstílus alapú szegmentáció napjainkban is az egyik leghatékonyabb a pszichográfiai szegmentációs eljárások között (Lee \& Sparks 2007). A sportfogyasztás esetén a pszichografikus eljárások a fentebb leírtak alapján kiemelt szerephez jutnak, ami már önmagában is megerösíti az életstílus-kutatások használatának érvényességét a sportfogyasztói magtartás feltérképezésében.

Az életstílus alapú szegmentáció az egyszerübb demográfiai alapú szegmentációs eljárásokhoz képest szélesebb bázisú, a fogyasztók mindennapjaira koncentráló nézetet képviselve. Ebbe beletartozik a mindennapi tevékenységeik széles köre, az érdeklődési körük, és az egyes dolgokról alkotott véleményük is (Plummer 1974).

$\mathrm{Az}$ életstílus kutatások marketingkoncepcióba történő implementálása óta számos életstíluskutatás született jól tematizált elméleti és módszertani kiindulóponttal, amelyek nagy hatással voltak a marketingalkalmazásokra. Töröcsik (2011) 
munkájában részletesen összegyüjtötte a legfontosabb nemzetközi életstílus vizsgálatokat, amik az AIO-kutatások, a VALS-kutatások, a kultúrantropológiai közelítés, a Sinus-miliő koncepció, a Szemiotikai közelítés, a GIM rendszer, a Research Institute on Social Change intézet módszere, és az etnografikus életstílus vizsgálatok. A nemzetközi tendenciákhoz képesti késéssel Magyarországon is egyre népszerübbé váltak az életstílus-kutatások, kezdetben a szociológusok körében (életmódkutatásokkal), de később üzleti célokat szolgáló módon a marketingkutatók között is. Törőcsik és tsai (2019) átfogóan összegyüjtötték a nemzetközi és a magyarországi életstílus kutatások rendszereit. A magyarországi kutatások között van a VALS és a VALS 2 kutatás, a TGI-kutatás, a Magyar Gallup Intézet kutatása, a Sinus-miliő magyarországi kutatása, az Euro-Socio-Stlyes, a 4C's kutatásának magyar eredményei, a GfK saját modelljén alapuló kutatása, a GfK-Tárki-kutatás, a Szegedi Tudományegyetem „Életstílus alapú fogyasztói szegmentumkutatás" elnevezésű projektje és a sportfogyasztás szempontjából kiemelt fontosságú Életstílus Inspiráció-modell.

Az Életstílus Inspiráció-modell a többi modellhez képest az értékorientáció mellett az élettempót veszi figyelembe az életstíluscsoportok meghatározásához (Törőcsik 2011). Ez a sportfogyasztás vizsgálata szempontjából fontos jellemző, mivel az élettempó eltérő szintje eltérő szabadidőt is jelent. Az Életstílus Inspiráció-modell ezen jellemzője kedvezővé teszi alkalmazását a sportfogyasztási kutatások esetében, mert a sportfogyasztás esetén az anyagi lehetőségek mellett időre is szükség van a sporttevékenységek aktív végzéséhez és a sportesemények megtekintéséhez is (András 2015). $\mathrm{Az}$ életstílus sportfogyasztói magatartásra gyakorolt hatásainak vizsgálatához emiatt megfelelö választás lehet az Életstílus Inspiráció-modell, aminek alapjait Törőcsik (2003) fektette le, majd munkatársaival validálta a modellt hazai körülmények között.

\section{LEHETSÉGES KUTATÁSI IRÁ- NYOK A SPORTFOGYASZTÁSBAN POSSIBLE RESEARCH DIREC- TIONS IN SPORT CONSUMPTION}

A sportgazdaságban tevékenykedő vállalatok számára az egyre több szereplö miatt, sikerességük elérésének érdekében a marketing szerepe felértékelödik. A sportfogyasztás akadémiai szakirodalma általánosan három fő területtel foglalkozik, amik a sportolásban történő aktív részvétel, a sport- események nézőként történő fogyasztása, illetve a sporttermékek fogyasztása (Shank 2004, Stewart et al. 2003, Fernandes et al. 2013). A szakirodalom ezeket a kategóriákat az esetek döntő részében egymástól elszigetelten próbálja értelmezni és vizsgálat alá venni, így külön-külön adva következtetéseket az egyes kategóriákról.

Meglátásaink szerint a sportfogyasztás kategóriái nem csupán három csoportba sorolhatók, hanem - kiegészítve az általában elfogadott felosztást - minimum ötbe. Egyrészt célszerü a sporteseményeken nézőként történő részvételt, ami tulajdonképpen egy élményfogyasztás, offline és online kategóriákra bontani. Ezt az online élménylehetőségek napjainkban tapasztalható megerösödése indokolja, elismerve az internet, a virtuális világ befolyását. Másrészt külön kategóriába kell sorolni azt a típusú sportolással kapcsolatos fogyasztást, ami a laikus, amatőr szint mellett a megélhetés és egzisztencia biztosításához kapcsolódik, ezáltal a profi versenyzők és az azokat kiszolgálók világába vezet (Csóka - Törőcsik 2018). Az így létrejövő sportolás, mint megélhetés kategóriájának érvényességét bizonyítja, hogy az Európai Unióban a munkavállalók 2,12\%-a, azaz majdnem 4,5 millió ember dolgozik valamilyen sporthoz kapcsolódó szervezetben (SpEA 2012).

Az egyes kategóriák elkülönített vizsgálata egyrészt a kategória jellemzők esetén tapasztalható jelentős különbségek miatt indokolt, és magukról a sportfogyasztási kategóriákról rengeteg értékes információt szolgáltat, másrészről a valóságban ezek a kategóriák nem egymástól elkülönítetten, hanem egymással fedésben léteznek, így ezekkel a közös területekkel is érdemes foglalkozni. Az elkülönített vizsgálatok miatt az egyes kategóriák dimenziójában értékes információk maradhatnak rejtve a kutatók és ezáltal a gyakorlati szakemberek elől. Így célszerü az egyes sportfogyasztási kérdéseket a kategóriák teljes keresztmetszetében is megvizsgálni a folyamatok jobb megértése céljából.

A hagyományos kategorizálás, ami három csoportra osztja a sportfogyasztást, föként gazdasági szempontból közelíti meg a fogyasztás kategóriáit. Az öt fogyasztási területü modell (1. ábra) a fogyasztók szemszögéből értelmezett, a valóságos sportfogyasztói magatartáshoz közelebb álló kategorizálást tesz lehetővé. Emiatt a holisztikus fókuszú munkák során, ahol nem a különálló fogyasztáskategóriák, hanem a fogyasztói döntések elemzése a cél ez a kiterjesztett modell jobb kiindulási alapot jelenthet. 


\section{1. ábra: A sportfogyasztás kiterjesztett értelmezése: az öt fogyasztási területủ modell \\ Figure 1. The extended interpretation of sport consumption: \\ the five area model of sport consumption}

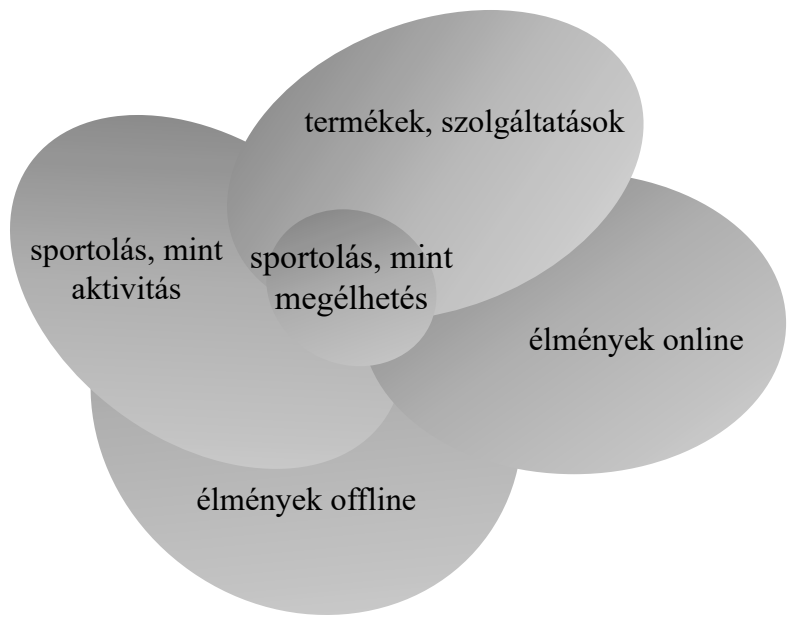

Forrás: Csóka - Töröcsik 2018

A sportfogyasztás vizsgálatában a sportfogyasztók motivációinak ismerete sokszor kulcskérdés. Ezt bizonyítja az is, hogy sportmotivációs kutatásokkal számos ország számos kutatója foglalkozik (Clancy et al. 1995, Paic és tsai 2018). Ennek ellenére nem sikerült azonosítani a sportfogyasztás teljes keresztmetszetében történő vizsgálatot a sportfogyasztás motivációinak vizsgálata kapcsán. A sportfogyasztáshoz köthető motiváció kutatások minden feltárt esetben egy adott kategóriára fókuszáltak, aszimmetrikus módon leginkább a sportolásban történő aktív részvételre, vagy a sportélmények nézőként történő offline fogyasztására (Pelletier et al. 1995, Lonsdale et al. 2014, Funk et al. 2001). Mivel feltételezésünk szerint a sportfogyasztás kategóriái egymással fedésben állnak, ezért célszerü lenne a motivációk kategóriánként elszigetelt vizsgálatán túl a kategóriák mindegyikén átívelő keresztmetszeti vizsgálat is, amely a sport iránti alapvető érdeklődést vizsgálná, ebből levezetve a sportfogyasztás motivációit. Elismerve a sport iránti alapvető érdeklődés szerepét, módosítva az öt fogyasztási területủ modellt (1. ábra) létrejön a fogyasztó-központú modell (2. ábra), aminek szemlélete az érdeklődésen (motiváción) keresztüli vetítés. Azaz, feltételezzük, hogy a sport iránti alapvetö érdeklödés más, magasabb szintü motivációt eredményezhet minden egyes sportfogyasztási kategória esetében. Ennek vizsgálata a sportfogyasztás szakirodalmában hiánypótló lenne. 
2. ábra: A sportfogyasztás kiterjesztett értelmezése: a fogyasztó-központú modell Figure 2. The extended interpretation of sport consumption: the consumer-centric model

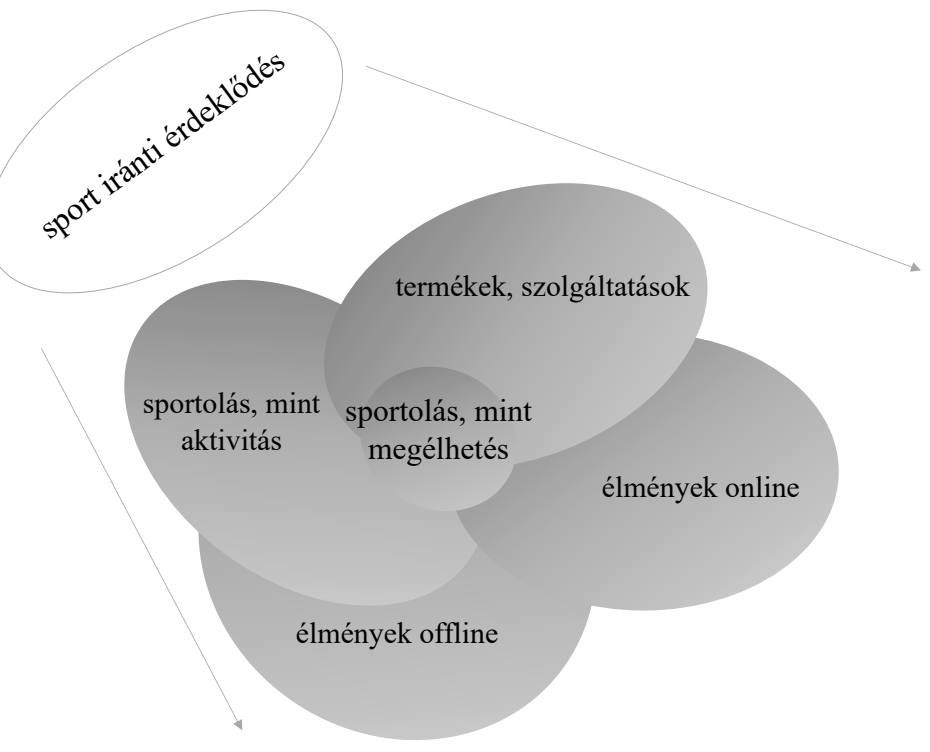

Forrás: saját szerkesztés

A másik terület, ahol a szakirodalomban hiányosságot sikerült felfedezni, az az életstílus hatása a sportfogyasztásra. Marketing szempontból az életstíluscsoportok megfelelő közelítését adják a témának, hiszen az életstílus-kutatások egyértelmüen kimutatták, hogy az emberek életstílusa alapjaiban befolyásolja fogyasztói magatartásukat (Törőcsik - Szücs 2019). A sportmarketing felé közelítve ezt a jellemzőt teljesen egyértelmü, hogy a különböző életstíluscsoportok tagjai teljesen más sportfogyasztási jellemzőkkel és sportfogyasztási motivációkkal rendelkezhetnek, amik alapjaiban befolyásolják a sportfogyasztói magatartásukat. Az életstílus-kutatásokat illetően több kutató foglalkozott az egyes életstílus csoportok fogyasztásának jellemzőivel (Conrad \& Burnett 1985, SinusInstitut 2015, Solomon et al. 2010), de ezekben a sport tulajdonképpeni fogyasztása csak kis súlyt kapott. Az életstílus-csoportok esetén a sportfogyasztást középpontba helyező kutatást egyáltalán nem sikerült azonosítani. Célszerü lenne a sportfogyasztás kategóriáinak és motivációinak összefüggését a különböző életstílus csoportok dimenziójában feltárni. Azaz, másik kutatási feltételezésünk, hogy a sportfogyasztás jellege eltérö a különbözó életstíluscsoportokban.
Az életstíluscsoportok sportfogyasztási jellemzőinek és a mögöttük húzódó motivációknak megismerése és felderítése alapjaiban segítheti a sportvállalatok marketingmunkáját, de akár kormányzati döntések elökészítését is támogathatja. Ezen ismeretek birtokában pontosabban határoznák meg a célcsoportokat, ami megteremtené a kínálat jobb pozícionálási lehetőségét is. Napjaink sportgazdaságában a számos szereplö és az éles verseny miatt ez egy adott sportvállalat sikerességének szempontjából kulcskérdés lehet.

\section{ÖSSZEFOGLALÁS SUMMARY}

A tanulmányban sikerült meghatározni a sportfogyasztói magatartás vizsgálatához kapcsolódóan három olyan fontos témakört, amikkel szükségesnek tűnik a sportfogyasztás szakirodalmát kiegészíteni. Az első ilyen témakört a sportfogyasztás kategorizálása jelenti. A sportfogyasztási kategóriák értelmezése során a jelenleg elterjedt modell a gazdaság szempontjából közelíti meg a fogyasztói magatartást és klasszikusan három különböző kategóriára bontja azt. A fogyasztók szemszögéből értelmezett, emiatt a valóságos sportfogyasztói 
magatartáshoz közelebb álló kategorizáláshoz ezt az elképzelést ki kell bővíteni. Erre kínálhat megoldást a fogyasztó-központú közelítés, ami a klasszikus három kategória helyett ötbe osztja a sportfogyasztás elemeit és a kategóriák közötti átfedésekkel is foglalkozik.

A második témakör, ami esetén hiány mutatkozik a szakirodalomban az a sportfogyasztási mögötti motivációk vizsgálatának holisztikus közelítése. Az egyes sportfogyasztási kategóriákon belül számos motivációkutatás található, viszont a kategóriák határait átlépő általános közelítés alig. Feltételezzük, hogy a sport iránti alapvető érdeklődés más, magasabb szintű motivációt eredményezhet minden egyes sportfogyasztási kategória esetében. Emiatt célszerü a fogyasztó-központú közelítés alapján megvizsgálni, hogy a sportfogyasztás teljes rendszere szempontjából mit jelent az egyes sportfogyasztók sport iránti érdeklődésének szintje. Kérdés, hogy ez miként befolyásolja a sportfogyasztói döntéseket és az egyes sportfogyasztási kategóriák esetén tapasztalható fogyasztás jellemzőit.

Harmadik fontos témakör a sportfogyasztási kutatások lehetséges jövőbeli irányait illetően, az életstílus hatása a sportfogyasztásra. Feltételezhető, hogy a sportfogyasztás jellege eltérő a különböző életstíluscsoportokban. A feltételezés helyességét megerősíti, hogy számos kutató említi, hogy az életstílus alapjaiban befolyásolja a sportfogyasztást. A szakirodalomban mégis hiány mutatkozik a sportfogyasztást középpontba helyező életstílus-kutatásokat illetően. Ezt a hiányt lenne célszerü pótolni az Életstílus Inspiráció-modell segítségével a sportfogyasztási kategóriák és azok motivációinak dimenzióiban. A jelen tanulmányban felrajzolt három kutatási lehetőségre reagálva, későbbi publikációkban teszünk kísérletet kutatótársaimmal a szakirodalom gazdagítására primer elemzések segítségével.

\section{HIVATKOZÁSOK REFERENCES}

András K. (2015), „A hivatásos sport gazdaságtani alapjai”, in: Ács P. (szerk) Sport és Gazdaság, Pécs: Pécsi Tudományegyetem Egészségtudományi Kar, 434 - 481

András K., Máté T. (2016), „Hazai rendezésü megasportesemények gazdasági hatása”, START, $1(1), 13-24$

Ács P. (2017), „A fizikai inaktivitás nemzetgazdasági terheinek és a sportfogyasztásának változása Magyarországon az elmúlt időszakban”, Magyar Sporttudományi Szemle, 18(70), 27

Conrad, M., Burnett, L. (eds) (1985), Life Style Research 1985, Frankfurt am Main, Michael Conrad \& Leo Burnett

Csóka L. (2019), „A sportfogyasztási kutatások iránya az elmúlt tíz évben”, in: Veres Z., Sasné Grósz A., Liska F. (szerk.), Ismerjük a vevöt? A vásárlás pszichológiája, Az Egyesület a Marketingoktatásért és Kutatásért XXV. Országos konferenciájának előadásai, Veszprém: Pannon Egyetem, 129-140

Csóka L., Törőcsik M. (2018), „A sportfogyasztás és a motivációit mérő skálák”, in: Józsa L., Korcsmáros E., Seres Huszárik E. (szerk.), A hatékony marketing, EMOK 2018 Nemzetközi Tudományos Konferencia konferenciakötete, Komárom: Selye János Egyetem, 57-71

Clancy, R. B., Herring, M-P., MacIntyre, T. E. and Campbell, M. J. (2016), "A review of competitive sport motivation research", Psychology of Sport \& Exercise, 27, 232-242. DOI: 10.1016/j. psychsport.2016.09.003

Fernandes, N.E., Correia, A.H., Abreu, A.M., Biscaia, R. (2013), "Relationship between sport commitment and sport consumer behavior", Motricidade Fundação Técnica e Científica do Desporto, 9(4), 2-11. DOI: 10.6063/motricidade.9(4).9

Funk, D. C., Filo, K., Beaton, A. A. and Pritchard, M. (2009), "Measuring the motives of sport event attendance: bridging the academic-practitioner divide to understanding behavior", Sport Marketing Quarterly, 18(3), 126-138

Funk, D. C., Mahony, D., Nakazawa, M. and Hirakawa, S. (2001), "Development of the Sport Interest Inventory (SII): Implications for measuring unique consumer motives at sporting events", International Journal of Sports Marketing and Sponsorship, 3(3), 291-316

Füller, J. and Matzler, K. (2008), “Customer delight and market segmentation: An application of the three-factor theory of customer satisfaction on life style groups", Tourism Management, 29, 116-126. DOI: 10.1016/j.tourman.2007.03.021

Hargitai D. M. (2013), ,A magyar sportszponzorációs piac Európa tükrében" in: Ferencz Á. (szerk.), 
Környezettudatos gazdálkodás és menedzsment, Gazdálkodás és Menedzsment Tudományos Konferencia, Kecskemét: Kecskeméti Főiskola Kertészeti Főiskolai Kar, 328-332

Kajos A., Prisztóka Gy., Paic R. (2017), „A nézőtéri sportfogyasztás motivációit mérő, magyar nyelvü „SPEEDE-H” skála validációja és néhány eredménye", Vezetéstudomány / Budapest Management Review, 43(10), 19-31. DOI: 10.14267/VEZTUD.2017.10.03

Lee, S. H. and Sparks, B. (2007), "Cultural influences on travel lifestyle: A comparison of Korean Australians and Koreans in Korea", Tourism Management, 28, 505-518. DOI: 10.1016/j.tourman.2006.03.003

Lonsdale, C., Hodge, K., Hargreaves, A. E. and Johann, Y.Y. (2014), "Comparing sport motivation scales: A response to Pelletier et al.", Psychology of Sport and Exercise, 15(5), 446-452. DOI: 10.1016/j.psychsport.2014.03.006

Matzler, K., Bailom, F., Hinterhuber, H. H., Renzl, B. and Pichler, J. (2004), 'The asymmetric relationship between attribute level performance and overall customer satisfaction: A reconsideration of the importance-performance analyses", Industrial Marketing Management, 33(4), 271-277. DOI: 10.1016/S0019-8501(03)00055-5

Milne, G. R. and McDonald, M. A. (1999), Sport marketing: Managing the actual exchange process, Sudbury, MA: Jones and Bartlett Publishers

Mullin B., Hardy, S. and Sutton W. (2014), Sport Marketing, 4th ed., Champaign, IL: Human Kinetics

Neulinger Á. (2007), Társas környezet és sportfogyasztás. A folyamatos megerösitést igénylö tanult fogyasztás, Doktori ( $\mathrm{PhD})$ értekezés, Budapest: Budapesti Corvinus Egyetem, Gazdálkodástani Doktori Iskola

Paic R., Kajos A., Meszler B., Prisztóka Gy. (2018), „A magyar nyelvü Sport Motivációs Skála (H-SMS) validációja és eredményei”, Magyar Pszichológiai Szemle, 73(2), 159-182. DOI: 10.1556/0016.2018.002

Pelletier, L. G., Fortier, M. S., Vallerand, R.J., Tuson, K. M., Brie're, N.M. and Blais, M. R. (1995), "Toward a new measure of intrinsic motivation, extrinsic motivation, and amotivation in sports: the Sport Motivation Scale (SMS)", Journal of Sport and Exercise Psychology, 17, 35-53

Pelletier L. G., Rocchi M.A., Vallerand R.J., Deci E.L. and Ryan M.R. (2013), "Validation of the revised sport motivation scale (SMS-II)", Psychology of Sport and Exercise, 14(3), 329-341. DOI: 10.1016/j.psychsport.2012.12.002

Plummer, J. T. (1974), “The Concept and Application of Life Style Segmentation", Journal of Marketing, 38(1), 33-37. DOI: 10.2307/1250164

Salgado-Barandela, J., Barajas, A., Sánchez-Fernández, P. (2017), "Economic impact of sport: Topic of growing interest for the scientific literature", Revista Internacional de Medicina y Ciencias de la Actividad Física y del Deporte, 17(68), 729755. DOI: 10.15366/rimcafd2017.68.010

Shank, M. D. (2009), Sports Marketing - A Strategic Perspective, Upper Saddle River: Pearson Prentice Hall

Sinus Institut (2015), Sinus-Milieus in English, Heidelber, Sinus-Institut.

SpEA (2012), Study on the Contribution of Sport to Economic Growth and Employment in the EU. Study Commissioned by the European Comission, Directorate-General Education and Culture Final Report, Austria: SportsEcon

Solomon, M. R., Bamossy, G., Soren, A. and Hogg, M. K. (2010), Consumer Behaviour: A European Perspective, Harlow: FT Prentice Hall

Stewart, B., Aaron, C., Smith, T. and Nicholson, M. (2003), "Sport consumer typologies: A critical review", Sport Marketing Quarterly, 12(4), 206216

Szabó Á. (2015), „A szabadidősport gazdasági kérdései”, in: Ács P. (szerk), Sport és Gazdaság, Pécs: Pécsi Tudományegyetem Egészségtudományi Kar, 482 - 526

Szakály Z., Fehér A. (2015), Sportmarketing, Debrecen: Campus Kiadó

Törőcsik M. (2003), Fogyasztói magatartás, trendek, Budapest: KJK-Kerszöv.

Törőcsik M. (2011), Fogyasztói magatartás: insight, trendek, vásárlók, Budapest: Akadémiai Kiadó

Törőcsik M., Csóka L. (2018), Sportfogyasztás. A magyar lakosság sportolással, sportfogyasztással kapcsolatos magatartása, beállitódása - országosan reprezentativ személyes megkérdezés eredményei, Pécs: PTE KTK

Törőcsik M., Szűcs K., Nagy Á., Lázár E. (2019), „Életstílus kutatások és a marketing. Életstílus-csoportok Magyarországon a digitalizáció korában", Replika, Társadalomtudományi Folyóirat, 111(Különszám), 63-86. DOI: $10.32564 / 111.5$

Trail, G. and James, J. (2001), "The motivation scale for sport consumption: assessment of the scale's psychometric properties", Journal of Sport Behavior, 24(1), 108-127

Walker, S., Enz, M. (2006), "Impact of Professional Sports on the Local Economy", Western New England Law Review, 29(1), 149-164

Wann, D. (1995), "Preliminary validation of the sport fan motivation scale", Journal of Sport and Social Issues, 19(5), 377-396. DOI: 10.1177/019372395019004004

Web of Science (é.n.): Search: Toward a new measure of intrinsic motivation, extrinsic motivation, and amotivation in sports: the Sport Motivation Scale (SMS), 
Csóka László, PhD hallgató csoka.laszlo@ktk.pte.hu

Pécsi Tudományegyetem

\section{Impact of motivation and lifestyle on sport consumption}

\section{THE AIMS OF THE PAPER}

The aim of the study is to identify areas where the literature of sport consumption can be further enriched, thereby identifying possible areas for future research. Sport marketing experts usually divide sport consumption into three different fields, which are active participation in sports, consumption of sport events as experiences, and consumption of sporting goods. In most cases scientific researchers deal with these fields separately and only concentrate on one of them. Due to separate studies, valuable information may remain hidden from the researchers and thus from practitioners. A further aim of the study is to draw attention to comprehensive phenomena that would allow for a better understanding of the processes by examining sport consumption issues across the categories.

\section{METHODOLOGY}

For our findings we made this review type article by using the wide range of marketing and sports marketing literature.

\section{MOST IMPORTANT RESULTS}

From the consumption's point of view, it would be expedient to extend the classical categorization of sport consumption and widen it with two further categories. This is also true in the field of sport consumption motivation, as there are many separate studies, but few with comprehensive focus across different categories. It would be important to examine the effects of basic interest in sport (motivation) on sport consumption categories, which would be a new idea compared to the popular category-specific research. Also a new research direction would be the study of the impact of lifestyle on sport consumption. The role of lifestyle in sport consumption is recognized by many researchers, however the literature of this type of research field is very limited.

\section{RECOMMENDATIONS}

The relevance of these research topics is demonstrated by the fact that with the knowledge provided, sports related companies can segment and form target groups more precisely, which would also create the possibility of better positioning. In today's sport economy, due to the numerous players and fierce competition, this could be a key issue for the success of a particular sport companies.

Keywords: sport consumption, consumer behaviour, lifestyle groups, sport marketing

Acknowledgements: This research was partially supported by the Human Resource Development Operational Programme, grant No.: EFOP-3.6.2-16-2017, Cooperative Research Network in Economy of Sport, Recreation and Health. 